\title{
Appendiceal Carcinoma pTis TNM Finding v7
}

National Cancer Institute

\section{Source}

National Cancer Institute. Appendiceal Carcinoma pT is TNM Finding v7. NCI Thesaurus. Code C89897.

Appendiceal carcinoma with a finding of carcinoma in situ: intraepithelial or invasion of the lamina propria. T is includes cancer cells confined within the glandular basement membrane (intraepithelial) or lamina propria (intramucosal) with no extension through muscularis mucosae into submucosa. (from AJCC 7th Ed.) 